\title{
The Validity Of The Guided Inquiry Learning Model Tool to Train Students' Scientific Literacy Skills
}

\author{
Riza Dwi Puspitasari, Sri Poedjiastoeti, Pirim Setiarso \\ Science Education, Post Graduate \\ Universitas Negeri Surabaya \\ sripoedjiastoeti@unesa.ac.id
}

\begin{abstract}
This study aims to produce learning tools that are feasible to be used in the learning process. Learning tools developed are oriented towards guided inquiry models that aim to train students' scientific literacy skills. Learning tools consist of syllabus, lesson plans, student worksheets, and assessment sheets. The research instrument used is a learning device validation sheet. Learning devices are validated by three validators. The validation results of the three validators show that the developed device has a very valid category.
\end{abstract}

Keywords - Validity, Learning Tools, Guided Inquiry, Scientific Literacy

\section{INTRODUCTION}

Science is related to how to systematically find out about nature so that science is not only mastering a collection of knowledge in the form of facts, concepts or principles, but also a process of discovery. Science education emphasizes giving direct experience to develop competencies so that students are able to explore and understand the natural surroundings scientifically [1]. Chemistry is one of the branches of science in the science family. Chemistry is a science that was originally obtained and developed based on experiments but in subsequent developments chemistry was also obtained and developed based on theory [2]. This shows that chemical learning is closely related to basic concepts and everyday life. Based on this learning, especially chemistry, it is necessary to apply meaningful learning so that students can more easily understand each concept obtained. Meaning in science learning for students can be obtained if students have good scientific literacy skills.

Scientific literacy is the ability of a person to use scientific ability, understand and apply (oral and written) scientific knowledge to solve problems so that they have high attitudes and sensitivity towards themselves and their environment, actively participate and intelligently handle science-based problems in society and make decisions based on consideration scientific considerations [3]. the development of scientific literacy is very important because it can contribute to social and economic life and to improve decision making at the community and personal level [4].
Education experts are currently trying to improve students' scientific literacy skills so that students can apply the knowledge gained to overcome problems that arise in everyday life.

According to PISA 2015 good scientific literacy can give students the ability to explain scientific phenomena, evaluate, design scientific investigations, and interpret scientific data or evidence. Scientific literacy skills according to PISA have a framework that is interconnected between 4 aspects, namely contexts, competencies, attitudes, and knowledge. Literate people are people who have to understand relationships and society, understand processes and processes, have basic conceptual or conceptual knowledge, and understand the relationship between life and life or as part of life [5]. Indonesian students' scientific literacy based on the results of the PISA study from 2000-2009 has decreased [6].Based on this, it is necessary to improve learning to improve students' scientific literacy skills. One way to improve the learning process can use the learning model. One learning model that can be used to improve scientific literacy skills is a guided inquiry learning model.

Inquiry learning model is a series of learning activities that emphasize the process of thinking critically and analytically to find and find answers to a question in question. According to the American Association for the Advancement of Science [6], inquiry-based teaching methods can be used to achieve scientific literacy because it provides students with opportunities to discuss and debate scientific ideas. Inquiry learning models are related to scientific literacy. This is evidenced by a statement based on [7], that the inquiry learning process is guided in line with the domain framework of scientific literacy competency which includes the explanation of scientific phenomena, evaluating, and designing scientific research and interpreting scientific data and evidence.

Efforts to improve learning are carried out through research. The studies that have been carried out have not stated about the validity and reliability of the devices used in learning. Research results can be used as a basis for alternative learning that can improve students' scientific literacy skills. before conducting research, researchers must design valid learning tools to show valid research results [8]. Therefore, researchers conducted research to develop 
valid and reliable learning tools, so that they were suitable to be used to improve students' scientific literacy skills.

\section{METHODS}

This study aims to determine the validity of the learning tools developed, namely guided inquiry-oriented learning tools to train students' scientific literacy skills. The learning tools consist of syllabus, Learning Implementation Plan (RPP), Student Activity Sheet (LKS), student assessment of scientific literacy skills. Learning tools are developed for students of class XI acid base material which includes sub material development theory of acid base, acid base indicator, acid base $\mathrm{pH}$.

The research instrument used is a learning device validation sheet. The validation sheet is in the form of a questionnaire, so the validator gives an assessment by giving a checklist $(\sqrt{ })$ in the column range of scores 1-4. Every aspect is assessed by referring to the validity rating scale in Table I [9]

TABLE I. VALIDITY RATING SCALE

\begin{tabular}{|c|c|}
\hline Assessment & Value/score \\
\hline Very good & 4 \\
\hline Good & 3 \\
\hline Poorly good & 2 \\
\hline Not good & 1 \\
\hline
\end{tabular}

The data obtained from the validity were analyzed by calculating the average value given by the validator, then described according to the assessment criteria of the device listed in Table II [9]

TABLE II. ASSESSMENT CRITERIA FOR LEARNING DEVICES

\begin{tabular}{|c|c|c|}
\hline $\begin{array}{c}\text { Value } \\
\text { Interval }\end{array}$ & Value Category & Explanation \\
\hline $3,5 \leq \mathrm{P} \leq 4,0$ & Very Valid & $\begin{array}{c}\text { Can be used without } \\
\text { revision }\end{array}$ \\
\hline $2,9 \leq \mathrm{P} \leq 3,4$ & Valid & $\begin{array}{c}\text { Can be used with } \\
\text { revision }\end{array}$ \\
\hline $2,3 \leq \mathrm{P} \leq 2,8$ & Enough & $\begin{array}{c}\text { Can be used with } \\
\text { revision }\end{array}$ \\
\hline $1,7 \leq \mathrm{P} \leq 2,2$ & Poorly Valid & $\begin{array}{c}\text { Can be used with } \\
\text { revision }\end{array}$ \\
\hline $1,0 \leq \mathrm{P} \leq 1,6$ & Invalid & Don,t can be used \\
\hline
\end{tabular}

Furthermore, the percentage of reliability calculation is conducted which aims to determine the similarity of values given by three validators. The data listed in the table of research results is the reliability obtained from three validators (V1-2, V2-3, V1-3) with a range of $85.7 \%$ $100 \%$. Reliability is calculated using the following formula [10]

Percentage of Agreement $(R)=\left[1-\frac{A-B}{A+B}\right] \times 100 \%$

Explanation:

$\mathrm{R}=$ reliability coefficient
$\mathrm{A}=$ The results of the assessment by observers who give high marks

$\mathrm{B}=$ The result of the assessment by the observer that gives a low value.

An instrument for evaluating learning devices is said to be reliable if the percentage of agreement obtained is $\geq 75 \%$ [10]. Based on the criteria in Table II, the developed learning tools are said to be valid if they get a score of 92.9 which is fulfilling the minimum valid category. conclusions reliability of each device is determined from the category that most often appears in the assessed aspect (mode).

\section{RESULT AND DISCUSSION}

\section{A. Results}

The validation results of each learning device are described as follows

1. Validation of the syllabus

Syllabus developed based on the revised 2013 curriculum. Validation results are shown in Table III.

TABLE III. RESUlts OF VALIDATION OF THE Syllabus

\begin{tabular}{|c|l|c|c|c|}
\hline Number & $\begin{array}{c}\text { Assessment } \\
\text { of aspect }\end{array}$ & $\begin{array}{c}\text { Average } \\
\text { of score }\end{array}$ & Category & R(\%) \\
\hline 1. & Identity & 4 & $\begin{array}{l}\text { Very } \\
\text { valid }\end{array}$ & $85,7-100$ \\
\hline 2. & $\begin{array}{l}\text { Suitability of } \\
\text { the syllabus } \\
\text { with the } \\
\text { applicable } \\
\text { curriculum }\end{array}$ & 4 & $\begin{array}{l}\text { Very } \\
\text { valid }\end{array}$ & $85,7-100$ \\
\hline 3. & $\begin{array}{l}\text { Suitability of } \\
\text { indicators } \\
\text { with basic } \\
\text { competencies }\end{array}$ & 3,67 & $\begin{array}{l}\text { Very } \\
\text { valid }\end{array}$ & $85,7-100$ \\
\hline 4. & $\begin{array}{l}\text { Suitability of } \\
\text { learning } \\
\text { activities with } \\
\text { indicators }\end{array}$ & 3,33 & Valid & $85,7-100$ \\
\hline 5. & $\begin{array}{l}\text { Suitability of } \\
\text { assessment } \\
\text { instruments }\end{array}$ & 3,67 & $\begin{array}{l}\text { Very } \\
\text { valid }\end{array}$ & $85,7-100$ \\
\hline
\end{tabular}

Based on Table III it can be seen that all aspects have an average of 3.33 - 4 with valid and very valid categories, based on the validity mode data is very valid. The reliability of the three validators reaches a range of $85 \%-100 \%$ with a reliable category.

\section{Validation of Learning Implementation Plans (RPP)}

The Learning Implementation Plan (RPP) developed consists of 3 meetings. RPP validation results are listed in Table IV

TABLE IV. RPP VALIDATION RESULT

\begin{tabular}{|c|l|c|c|c|}
\hline Number & $\begin{array}{c}\text { Assessment of } \\
\text { aspect }\end{array}$ & $\begin{array}{c}\text { Average } \\
\text { of score }\end{array}$ & Category & R (\%) \\
\hline 1 & Identity & 4 & Very valid & $85,7-100$ \\
\hline 2 & Aim & 3,72 & Very valid & $85,7-100$ \\
\hline 3 & $\begin{array}{l}\text { Learning } \\
\text { materials }\end{array}$ & 3,45 & Very valid & $85,7-100$ \\
\hline
\end{tabular}




\begin{tabular}{|c|l|c|c|c|}
\hline Number & $\begin{array}{l}\text { Assessment of } \\
\text { aspect }\end{array}$ & $\begin{array}{c}\text { Average } \\
\text { of score }\end{array}$ & Category & $\mathbf{R}(\mathbf{\%})$ \\
\hline 4 & $\begin{array}{l}\text { Facilities and } \\
\text { learning } \\
\text { resources }\end{array}$ & 3,67 & Very valid & $85,7-100$ \\
\hline 5 & Learning step & 3,72 & Very valid & $85,7-100$ \\
\hline 6 & Evaluation & 3,84 & Very valid & $85,7-100$ \\
\hline 7 & Language & 3,67 & Very valid & $85,7-100$ \\
\hline
\end{tabular}

Table IV shows that the average score of RPP validation results from the three validators of 3.45 - 4 is very valid, based on the validity mode data is very valid. The reliability percentage of the three validators reached a range of $85.7 \%$ $-100 \%$ with a reliable category.

\section{Validation of Student Activity Sheet (LKS)}

The Student Activity Sheet (LKS) which was developed consisted of 3 types of worksheets which included submaterial development of the theory of acid-base, acid-base indicator, acid-base $\mathrm{pH}$. LKS validation results are presented in Table V

TABLE V. RESULTS OF LKS VALIDATION

\begin{tabular}{|c|l|c|c|c|}
\hline Number & $\begin{array}{c}\text { Assessment } \\
\text { of aspect }\end{array}$ & $\begin{array}{c}\text { Avera } \\
\text { ge of } \\
\text { Score }\end{array}$ & Category & R (\%) \\
\hline 1 & Format & 3,72 & Very Valid & $85,7-100$ \\
\hline 2 & Language & 3,5 & Very Valid & $85,7-100$ \\
\hline 3 & Contents & 3,88 & Very Valid & $85,7-100$ \\
\hline
\end{tabular}

Table $\mathrm{V}$ shows that all aspects assessed in the developed LKS have a very valid category, as evidenced by the average score obtained is $3.33-4$, based on the data validity mode is very valid. The reliability obtained is $85.7 \%-100 \%$ with a reliable category.

\section{Validation of Assessment Sheets}

The assessment sheet consists of an assessment sheet in the context, competency, knowledge and attitude aspect assessment sheets. The results of the validation of the assessment sheet are presented in Table VI

TABLE VI. VALIDATION SHETt ASSESSMENT RESUltS

\begin{tabular}{|c|l|c|c|c|}
\hline Number & $\begin{array}{l}\text { Assessment } \\
\text { of aspect }\end{array}$ & $\begin{array}{c}\text { Average } \\
\text { of Score }\end{array}$ & Category & R (\%) \\
\hline 1 & $\begin{array}{l}\text { Assessment } \\
\text { sheet for } \\
\text { context, } \\
\text { competences } \\
\text { and } \\
\text { knowledge } \\
\text { aspect }\end{array}$ & 3,79 & $\begin{array}{l}\text { Very } \\
\text { Valid }\end{array}$ & $85,7-100$ \\
\hline 2 & $\begin{array}{l}\text { Assessment } \\
\text { sheet for } \\
\text { attitude } \\
\text { aspect }\end{array}$ & 3,67 & $\begin{array}{l}\text { Very } \\
\text { Valid }\end{array}$ & $85,7-100$ \\
\hline
\end{tabular}

Table VI shows that all aspects assessed in the developed assessment sheet have a very valid category, as evidenced by the average score obtained is $3.67-3.79$, based on the validity mode data is very valid. The reliability obtained is $85.7 \%-100 \%$ with a reliable category.

\section{B. Discussion}

The development of this tool starts from information analysis that aims to adjust the needs in learning and the tools developed to be effective in improving students' scientific literacy skills. The initial stage of information analysis is done by problem analysis, student analysis, material analysis, and curriculum analysis. After an information analysis is carried out the design of learning tools that are in accordance with the inquiry learning model and integrated with aspects of scientific literacy. after the learning device is designed, the learning tool will be tested by the expert by using the validity sheet.

The validity of the learning device is the result of the assessment of the learning device that is done by 3 experts obtained by using the learning device validation sheet. Learning devices are instruments to help and facilitate learning activities to achieve the specified goals [11]. Learning tools are needed to maximize learning goals. Learning tools developed are oriented towards guided inquiry models which aim to train students' scientific literacy skills in class XI for acid-base material.

The guided inquiry model is an inquiry learning model that presents problems, questions and material or supporting material determined by the teacher. Problems raised by the teacher give encouragement to students to conduct investigations in determining the answers [12]. Inquiry learning models are related to scientific literacy. It is proven that guided inquiry learning processes are in line with the domain framework of scientific literacy competencies which include explanation of scientific phenomena, evaluating, and designing scientific research and interpreting scientific data and evidence [7]. Science literacy trained in this study covers aspects of context, competence, knowledge, and attitude. The competency aspect consists of the ability to explain phenomena scientifically, the ability to design and evaluate scientific investigations, and the ability to interpret data and facts scientifically. While the aspect of knowledge consists of knowledge of content, procedural knowledge, epistemic knowledge.

Learning tools developed by the syllabus, Learning Implementation Plan (RPP), Student Activity Sheet (LKS), and assessment sheets. Each of these tools is oriented towards a guided inquiry model to train scientific literacy skills.

Framework of 2013 Curriculum, Ministry of Education and Culture No. 22 of 2016 concerning the standard process of primary and secondary education states that the syllabus developed based on graduate competency standards and content standards is used as a reference in the preparation of the learning framework for each subject matter study [14]. The syllabus is used as a reference 
framework in the development of RPP, LKS, and assessment sheets, so that the syllabus developed must be in a valid category, because it is used as a reference in developing learning tools. The syllabus that has been developed is used as a reference in developing the learning framework [15]. Based on the validation results listed in table III it can be said that the syllabus developed is feasible to use because all aspects have an average of 3.33-4 with valid and very valid categories, while the reliability obtained reaches a range of $85.7 \%-100 \%$, so the syllabus can be said to be reliable. This is in line with Borich's opinion [11], an instrument for evaluating learning devices is said to be reliable if the percentage of agreement obtained is $\geq 75 \%$.

The Learning Implementation Plan (RPP) developed consisted of 3 meetings, namely the first meeting on submaterial development of acid-base theory, the second meeting on acid-base indicator sub-material, and the third meeting on acid-base $\mathrm{pH}$ sub-material with each meeting having a time allocation of $2 \times 45$ minute. Learning activities in the RPP are adjusted to the steps of guided inquiry learning models that aim to train students' scientific literacy skills. the steps of the guided inquiry model used by Branch \& Oberg that includes Planning, Retrieving, Processing, Creating, Sharing, Evaluating [16]. Based on the validation results listed in table IV, it shows that the RPP developed has a valid category, the average score of RPP validation results from the three validators is $3.45-4$ with very valid categories. While the percentage of reliability of the three validators reached a range of $85 \%-100 \%$. Based on these results it can be said that the RPP developed is feasible to use because it has met the valid and reliable criteria.

The acquisition of RPP validity values with very valid categories is due to the suitability of the problems found with the solutions designed in the RPP. The suitability can be viewed from each aspect of the RPP that gets a relatively high value by each validator. The identity aspect has a very valid category because it includes education units, subjects, learning materials, classes, semesters, and time allocations, which have been adapted to the criteria in Permendikbud [14]. Aspects of learning objectives get a very valid category because it has been adapted to the syllabus developed. Aspects of learning step, get a very valid category due to the drafting of the lesson plan has been adjusted to the steps of guided inquiry according to Branch \& Oberg which includes Planning, Retrieving, Processing, Creating, Sharing, Evaluating [16].

Aspects of learning material also have valid categories. This is because the material written in the RPP is in accordance with the learning objectives, student development, and the specified time allocation. The language aspect has a very valid category, this is because the language, terms, clarity of letters and numbers used in the RPP are easy to understand and are in accordance with the Indonesian language rules.

The Student Activity Sheet (LKS) which was developed consisted of three types, namely LKS 1 on the development of the concept of sam bases, LKS 2 about acid-base indicators, LKS 3 about acid-base $\mathrm{pH}$. This worksheet is used at each meeting to support the learning process. This worksheet also refers to the steps of a guided inquiry learning model that aims to train students' scientific literacy skills. Based on the validation results obtained from the 3 validators listed in Table $\mathrm{V}$, all aspects assessed in the developed LKS have very valid categories, as evidenced by the average score obtained is $3.33-4$, while the reliability obtained is $85.7 \%-100 \%$. The developed LKS is feasible to use because it has met the criteria according to Borich, namely the percentage of agreement obtained $\% 75 \%$ [11] and also meets the criteria according to Riduwan that the developed learning device scores 92.9 which meets the minimum valid category [10].

The aspect of LKS assessment consists of aspects of format, language and content. The format aspect has a very valid category, this is because the distribution of the material contained in the LKS is clear, has the appeal, the type and size of the letters are appropriate and clear. The language aspect also has a very valid category, because the worksheets that are developed have grammar and sentences that are easy to understand and there are also instructions to work on. In addition, the content aspect also has a very valid category. This is because, the LKS has included the learning objectives contained in the RPP. In the developed worksheets also refers to the steps of guided inquiry and there are aspects of scientific literacy that will be trained, namely aspects of context, competence, knowledge and attitude.

The steps of guided inquiry refer to Branch \& Oberg which are 6 steps, namely Planning, Retrieving, Processing, Creating, Sharing, Evaluating. The first step is planning. The planning steps in the LKS contain learning objectives, instructions for using LKS, reading about daily phenomena and questions related to the phenomenon. This step can train the context literacy skills of the context, the competence to explain scientific phenomena, content knowledge, attitudes. The second step is retrieving, consisting of activities to obtain information, formulation of problems, activities to formulate hypotheses, and formulating experimental procedures. Retrieving steps can train context-based scientific literacy skills, scientific phenomenon explaining competencies, evaluating competencies and designing scientific investigations, content knowledge, procedural knowledge, attitudes. Furthermore, processing steps can train the competence to interpret data and scientific evidence, epistemic knowledge. The steps in the LKS consist of conducting experiments, writing experimental results, and analyzing data. The fourth step is creating. The step consists of activities to draw conclusions. In this step students are trained in scientific literacy skills in terms of competency in interpreting data and scientific evidence, epistemic knowledge. The sharing step can train the attitude aspect of scientific literacy skills in the form of presentation of the results of the discussion and ask the presentation group. The last step is evaluating. This step can train aspects of epistemic knowledge literacy skills, which consists of assessing other groups at the time of presentation and doing assignments given by the teacher. 
The developed assessment sheet consists of 2 types, namely the assessment of context, competency, knowledge and attitude assessment sheets. This assessment sheet is used to determine students' scientific literacy skills before and after the learning process. Based on the validation results of the three validators listed in Table VI, the average score was 3.67-3.79, while the reliability obtained was $85.7 \%-100 \%$. These results indicate that the assessment sheet developed is suitable for use because it meets the criteria according to Borich, the percentage of agreement obtained is $\geq 75 \%$ [11] and also meets the criteria according to Riduwan, that the developed learning device scores 92.9 which meets the minimum category valid [10]

Evaluation sheet on aspects of context, competence, knowledge has a very valid category. This is because the test questions are made in accordance with indicators, learning objectives, material, scientific literacy skills. In addition, the language and formulation of sentences used are arranged systematically, clearly and easily understood. The attitude aspect assessment sheet has a very valid category. The assessment sheet developed is in the form of a response questionnaire. The assessment sheet has a very valid category, because the statements on the questionnaire have included students' responses to subjects, the importance of chemistry in daily life, suitability and formulation of sentences have been systematically arranged.

\section{CONCLUSION}

Learning tools that are developed are learning-oriented devices that are guided inquiry models that are used to train students' scientific literacy skills. The learning tools consist of syllabus, lesson plans, student worksheets, and assessment sheets. All learning tools developed have a valid and very valid category so that they are suitable for use in the learning process.

\section{ACKNOWLEDGEMENT}

We thank Mr. Tukiran and Mr. Bambang Sugiarto from the Department of Chemistry, Universitas Negeri Surabaya for help in validation of the teaching materials.

\section{REFERENCES}

[1] Mendiknas, "Peraturan Menteri Pendidikan Nasional Republik Indonesia No. 23 Tentang Standar Kompetensi Lulusan untuk Satuan Pendidikan Dasar dan Menengah", Jakarta: Depdiknas, 2003.

[2] A. Rakhmawan, "Perancangan Pembelajaran Literasi Sains Berbasis Inkuiri Pada Kegiatan Laboratorium", Jurnal Penelitian dan Pembelajaran IPA, 2015, Vol. 1, pp. 145-154.

[3] U. Toharudin, S. Hendrawati, Rustaman, Andrian, "Membangun Literasi Sains Peserta Didik", Bandung: Humaniora, 2011.

[4] Laugksch, "Scientific Literacy: A Conceptual Overview", Rondebosch South Afrika: School of Educational University of Cape Town Private Bag.7701, 2000.

[5] J. Holbrook, M. Rannikmae, "The Meaning of Scientific Literacy", International Journal of Environmental \& Science Education., 2009, Vol. 4, No. 3, pp. 275-288.

[6] OECD, "PISA 2009 Results: What Students Know and Can DoStudent Performance in Reading, Mathematic, and Science (Volume 1), OECD Publishing:Paris-France, 2010.

[7] C. Gormally, P. Brickman, B. Hallar, N. Armstrong, "Effects of Inquiry-based Learning on Students' Science Literacy Skills and Confidence", Internatonal Journal for the Scholarship of Teaching and Learning. Volume 3, 2009.

[8] OECD, "PISA 2012 Assessment and Analytical Framework: Mathematics, Reading, Science, Problem Solving and Financial Literacy”, Paris: OECD Publishing, 2013.

[9] B. R. Wijaya, Y. S. Rahayu, R. Agustini, "Semester Learning Plan Validation of Guided Inquiry Based to Train Student's Scientific Argument Ability", SEELC, 2017.

[10] Riduwan, "Skala Pengukuran Variabel-Variabel Penelitian", Bandung: Alfabeta, 2012.

[11] G. D. Borich, "Observation Skill for Effective Teaching", New York: Mac Millan Publishing Company, 1994.

[12] N. A, Acevedo, W. Van Dooren, G. Clarebout, J. Elen, and L. Verschaffel, "Representational flexibility in linear-function problems: a choice/no-choice study". In L. Verschaffel, E. De Corte, T. de Jong and J. Elen (Eds.) Use or representations in reasoning and problem solving: Analysis and improvement, Milton Park, UK: Routledge, 2010, pp. 74-79.

[13] M. Ibrahim, "Pengembangan Perangkat Pembelajaran. Modul Disajikan pada Pelatihan Terintegrasi Berbasis Kompetensi Guru mata Pelajaran Biologi SLTP", Jakarta : Dirjen Dikdasmen Depdiknas, 2002.

[14] Mendikbud, "Peraturan Menteri Pendidikan dan Kebudayaan Nomor 22 Tahun 2016 Tentang Standar Proses Pendidikan Dasar dan Menengah”, Jakarta: Mendikbud, 2016.

[15] J. Suprihatiningrum, "Strategi Pembelajaran Teori \& Aplikasi", Jogjakarta: Ar-Ruzz Media, 2016.

[16] J. Branch, D. Oberg, "Focus on inquiry a teacher guide to implementing inquiry based learning", Canada: Alberta Education, Albert, 2004 